\title{
Ibu rumah tangga dan peningkatan ekonomi keluarga: Pemberdayaan perempuan di Home Industry Batik Tulis Dewi Rengganis Kabupaten Probolinggo
}

\author{
Nanda Widyasari, Siti Malikhah Towaf, I Dewa Putu Eskasasnanda* \\ Universitas Negeri Malang, Jl. Semarang No. 5 Malang, Jawa Timur, Indonesia \\ *Penulis korespondensi, Surel: dewa.putu.eskasasnanda.fis@um.ac.id
}

Paper received: 03-01-2021; revised: 15-01-2021; accepted: 30-01-2021

\begin{abstract}
Today's women are more free to move outside the home just like men. The phenomenon of working women occurs in different parts of the world, one of which is Indonesia. Women work because of the need for encouragement. Willingness and capacity and available employement opportunities and women's access to employment opportunities. It encourages women's demands pn equal rights with men or known as gender equality. The economic status pof womens is seen from their activities, access to factors of production, the level of income generated and the contribution to the family income. This article will discuss about the phenomenon of women working in the home industry batik Dewi Rengganis. in writing this article, the authors conducted research using descriptive qualitative method. The researchers act as observers. The research location is located in Jatiurip, Krejengan, Probolinggo Regency. Informants in this study are grouped into two, namely key informants and informats supporters. The data source used is primary data and secondary data.
\end{abstract}

Keywords: phenomenon; working women; home industry

\begin{abstract}
Abstrak
Perempuan masa kini memiliki keleluasaan untuk beraktivitas di luar rumah sama seperti kaum lakilaki. Mengikuti hal tersebut fenomena perempuan bekerja terjadi di berbagai belahan dunia, salah satunya di Indonesia. Perempuan bekerja dengan tujuan mencari nafkah terjadi karena dorongan kebutuhan, kemauan, kemampuan, serta kesempatan kerja yang tersedia. Selain itu, akses perempuan atas kesempatan juga sangat mempengaruhi. Hal tersebut mendorong terjadinya tuntutan yang dilakukan oleh kaum perempuan akan adanya kesetaraan gender. Status ekonomi perempuan dapat dilihat dari aktivitasnya dalam mencari nafkah, akses terhadap faktor produksi, tingkat pendapatan yang dihasilkan, dan kontribusinya terhadap pendapatan keluarga. Dalam artikel ini akan dibahas mengenai fenomena perempuan yang bekerja di Home Industry Batik Tulis Dewi Rengganis. Dalam penulisan artikel ini, penulis dalam melakukan penelitian menggunakan metode penelitian kualitatif deskriptif. Peneliti bertindak sebagai pengamat penuh. Lokasi penelitian berada di Desa Jatiurip Kecamatan Krejengan Kabupaten Probolinggo. Informan kunci dari penelitian ini adalah perempuan yang bekerja di Home Industry Batik Dewi Rengganis. Sumber data yang digunakan yaitu sumber data primer dan sumber data sekunder.
\end{abstract}

Kata kunci: fenomena; perempuan pekerja; home industry

\section{Pendahuluan}

Sebagai salah satu negara berkembang Indonesia dituntut untuk terus berusaha mengembangkan diri. Dari yang awalnya adalah masyarakat tradisional menuju masyarakat modern. Untuk itu potensi sumber daya harus dijadikan modal dalam negeri dan perlu dimanfaatkan secara optimal untuk mendukung pelaksanaan pembangunan nasional, terlebih lagi dalam memenuhi kebutuhan masyarakat. 
Tujuan utama pembangunan adalah untuk mencapai kehidupan sosial yang seimbang baik secara jasmani maupun rohani. Selain itu, pembangunan juga bertujuan untuk menyejahterakan kehidupan bangsa. Salah satu strategi untuk mencapai tujuan pembangunan adalah melalui upaya pemberdayaan masyarakat khususnya kaum perempuan. Dengan adanya kegiatan pemberdayaan ini diharapkan masyarakat dapat bersifat produktif. Untuk menciptakan masyarakat yang produktif, diperlukan berbagai macam upaya. Salah satu upaya tersebut yaitu dengan memberdayakan masyarakat khususnya perempuan.

Adanya pemberdayaan masyarakat terhadap perempuan akan berpengaruh terhadap produktivitas perempuan. Dengan hal tersebut kaum perempuan diharapkan menjadi tonggak dalam peningkatan kualitas baik masyarakat, bangsa, maupun negara. Pemberdayaan perempuan ini juga dianggap sebagai salah solusi alternatif dalam mengurangi jumlah kemiskinan. Hal ini karena dengan pemberdayaan perempuan yang berhasil akan menberikan pengaruh berupa penyerapan tenaga kerja dan peningkatan pendapatan, minimal pada tingkat keluarha. Oleh karena itu, kerja sama antar masyarakat dengan pemerintah maupun swasta akan sangat dibutuhkan. Salah satu contohnya adalah pemberdayaan perempuan melalui Home Industry Batik Tulis Dewi Rengganis di Kabupaten Probolinggo.

Home Industry Batik Tulis Dewi Rengganis dijalankan di Desa Jatiurip Kecamatan Krejengan Kabupaten Probolinggo. Di desa ini perempuan diberdayakan melalui program sosialisasi dan pendampingan dalam membuat batik tulis. Para perempuan di Desa Jatiurip Kecamatan Krejengan Kabupaten Probolinggo yang telah mendapatkan pendampingan mengenai teknik membatik, selanjutnya dapat menjadi pekerja di Home Industry Batik Tulis Dewi Rengganis.

\section{Metode}

Penelitian ini tergolong dalam jenis penelitian kualitatif dengan pendekatan deskriptif. Lokasi penelitian berada di Desa Jatiurip Kecamatan Krejengan Kabupaten Probolinggo. Sebagai sumber data primer, informan dalam penelitian ini dikelompokkan menjadi dua, yaitu informan kunci dan pendukung. Informan kunci adalah Ibu rumah tangga yang berkeja di Home Industry Batik Rengganis. Sementara informan pnedukung adalah pemerintah dan keluarga dari para ibu rumah tangga tersebut. Untuk memperolah data dari informan tersebut dilakukanlah kegiatan observasi, wawancara dan dokumentasi yang dilaksanakan secara simultan. Bersamaan dengan hal tersebut analisis data menggunakan teknik analisis data dengan model interaktif yang dilakukan secara terus menerus baik pada pengumpulan data, reduksi data, penyajian data, dan verifikasi/penarikan kesimpulan (Miles \& Huberman, 2002). Pengecekan keabsahan temuan dengan uji kredibilitas menggunakan triangulasi sumber, triangulasi teknik dan triangulasi waktu. Proses mulai dari pengumpulan data, reduksi data, penyajian data, dan penarikan kesimpilan dilakukan secara terus menerus sampai pada titik dimana data dikatakan jenuh dan mampu menjawab semua pertanyaan dalam penelitian ini.

\section{Hasil dan Pembahasan}

\subsection{Sejarah Berdirinya Home industry Batik Tulis Dewi Rengganis}

Home Industry Batik Tulis Dewi Rengganis didirikan pada tahun 2004 oleh perempuan yang biasa dipanggil dengan Hj. Rusyami. Home Industry Batik Tulis Dewi Rengganis didirikan berdasarkan pengalaman yang dirasakan oleh $\mathrm{Hj}$. Rusyami saat ia menjadi ibu rumah tangga secara penuh. Ia sering merasakan kejenuhan dan mebghabiskan waktu luangnya hanya 
dengan berdiam diri di rumah. Oleh karena hal tersebut $\mathrm{Hj}$. Rusyami berinisiatif untuk menjadi kader perubahan melalui kegiatan pemberdayaan perempuan melalui home industry.

Tujuan utama diadakannya pemberdayaan perempuan ini adalah untuk membantu kaum perempuan di Desa Jatiurip dalam memperoleh penghasilan tambahan dan membantu memenuhi kebutuhan sehari-hari. Para perempuan tidak akan memperdulikan pekerjaan yang mereka kerjakan (Nesneri \& Museliza, 2014). Adapun yang terpenting bagi mereka adalah mendapatkan pendapatan tambahan agar kebutuhan dapat terpenuhi.

Pada awal berdirinya Home Industry Batik Tulis Dewi Rengganis ini bergerak dibidang kerajinan manik-manik. Contoh kerajinan manik-manik yang dihasilkan berupa tas, dompet, dan sebagainya. Namun seiring berkembangnya waktu, industri manik-manik milik $\mathrm{Hj}$. Rusyami beralih menjadi industri konveksi. Hal ini dikarenakan minat konsumen terhadap kerajinan manik-manik yang sedikit sementara kebutuhan hasil industri konveksi meningkat dikawasan Kabupaten Probolinggo. Bermodal keterampilan Hj. Rusyami dalam dunia jahit menjahit dan modal yang terkumpul, akhirnya $\mathrm{Hj}$. Rusyami berani mengalihkan industri rumahan kerajinan manik-manik yang digelutinya menjadi industri rumahan konveksi.

Operasional industri konveksi Hj. Rusyami pun tidak bertahan lama. Hal ini dikarenakan Hj. Rusyami memantau minat konsumen dipasaran. Pada tahun 2010 Home industry ini mulai menekuni produksi batik tulis. Hal ini terjadi bukan tanpa alasan, melainkan dipengaruhi oleh beberapa faktor, yaitu jumlah pengrajin batik di Kabupaten Probolinggo yang masih sedikit, hal tersebut menggugah keinginan $\mathrm{Hj}$. Rusyami untuk menggeluti usaha produksi batik tulis khas Kabupaten Probolinggo. Selain itu pemerintah Kabupaten Probolinggo pada saat itu juga menunjuk Hj. Rusyami dan beberapa pemilik Home industry lain untuk mengikuti berbagai kegiatan pembinaan dan pelatihan mengenai tata cara produksi batik. Hal ini menjadi titik awal munculnya ketertarikan dan minat $\mathrm{Hj}$. Rusyami pada dunia perbatikkan.

Pada awal berdirinya Home Industry Batik Tulis Dewi Rengganis, pemasaran hasil industri batik masih belum mengenal sistem online. Pemasaran batik itu hanya dilakukan secara door to door oleh pemilik home industry Batik tersebut dengan dibantu oleh kedua rekan kerjanya. Hal ini dikarenakan keterbatasan pengetahuan $\mathrm{Hj}$. Rusyami pada saat itu tentang gadget. Sehingga pada saat itu sistem pemasaran yang ada masih mengandalkan sistem pemasaran tatap muka (secara langsung).

Seiring berkembangnya zaman, Home Industry Batik Tulis Dewi Rengganis mulai memasarkan hasil produksi batiknya secara online. Hal ini dikarenakan Hj. Rusyami dibantu oleh putri sulungnya yang merupakan alumni Universitas Brawijaya yang sudah memahami teknologi. Hj. Rusyami juga selalu melibatkan putri sulungnya tersebut untuk menjadi operator saat $\mathrm{Hj}$. Rusyami diminta mengisi kegiatan pelatihan disuatu daerah.

Dalam melakukan kegiatan produksi batik di Home Industry Batik Tulis Dewi Rengganis, Hj.Rusyami dibantu oleh beberapa pekerja yang jumlahnya dari tahun ke tahun semakin bertambah. Diawal berdirinya home industry Batik tulis Dewi Rengganis, Hj. Rusyami hanya dibantu oleh tiga pekerja. Hingga saat ini, jumlah pekerja di home industry Batik tulis Dewi Rengganis berjumlah 48 orang yang mayoritas berasal dari kaum perempuan. Menurut $\mathrm{Hj}$. Rusyami, para pekerja perempuan di Home Industry Batik Tulis Dewi Rengganis tidak hanya berlatar belakang sebagai ibu rumah tangga namun juga ada yang baru tamat dari sekolah langsung mendaftarkan diri untuk dilatih kegiatan membatik dan diperkerjakan di Home 
Industry Batik Tulis Dewi Rengganis. Selain itu juga ada beberapa pekerja laki-laki di Home Industry Batik Tulis Dewi Rengganis yang memiliki peran sebagai penggambar desain batik.

Berdasarkan hasil penelitian, $\mathrm{Hj}$. Rusyami sengaja membidik kaum perempuan di sekitar rumahnya untuk bekerja di home industry miliknya bukan tanpa alasan. Hal ini dikarenakan menurut $\mathrm{Hj}$. Rusyami menjadi ibu rumah tangga yang hanya berdiam diri di rumah adalah hal yang sangat membosankan. Berangkat dari pengalaman tersebut $\mathrm{Hj}$. Rusyami memiliki inisiatif untuk membuka usaha rumahan yang melibatkan masyarakat disekitar tempat tinggalnya, khususnya kaum perempuan. Dengan bergabung di home industry miliknya, Hj. Rusyami berharap agar perempuan-perempuan di desanya tidak hanya menjadi ibu rumah tangga yang produktif dan memanfaatkan peluang untuk mengasah kreativitas yang dimiliki untuk menambah pendapatan keluarga.

\subsection{Awal Mula Keterlibatan Perempuan di Desa Jatiruip terhadap Kegiatan Pemberdayaan}

Awal mula keterlibatan perempuan di Desa Jatiurip pada kegiatan pemberdayaan di Home Industry Batik Tulis Dewi Rengganis dikarenakan adanya beberapa hal. Pertama, adanya kesempatan kerja yang diberikan oleh Hj. Rusyami kepada para perempuan di Desa Jatiurip dan sekitarnya. Hasil temuan ini menunjukkan bahwa kesempatan kerja dapat tercipta dengan menumbuhkan dunia usaha (Sunartono, 2008). Salah satu yang bisa menyerap banyak tenaga kerja adalah sektor produksi. Perluasan ini dapat dikatakan sebagai dimensi ekonomi ketenagakerjaan dari adanya pemberdayaan. Hal ini karena melalui kesempatan kerja pertumbuhan ekonomi diciptakan sekaligus memberikan penghasilan dan meningkatkan daya beli masyarakat.

Kedua, adanya motif dan keinginan para perempuan di Desa Jatiurip untuk bekerja di Home Industry Batik Tulis Dewi Rengganis. Motif ekonomi menjadi alasan mendasar para perempuan di Desa Jatiurip bersedia terlibat dalam kegiatan pemberdayaan perempuan melalui Home Industry Batik Tulis Dewi Rengganis. Hasil temuan ini sesuai dengan pernyataan Rahaju, dkk (2012) yang menyebutkan bahwa latar belakang bekerja yang dimiliki poleh lakilaki dan perempuan memiliki perbedaan. Para pria berkerja karena memang kewajiban pria untuk mencari nafkah sebagai kepada keluarga. Sedangkan bagi perempuan, khususnya yang sudah nikah bekerja dapat berarti kegiatan untuk membantu perekonomian keluarga.

Ketiga, adanya keinginan untuk melatih kreativitas dan meningkatkan produktivitas para perempuan di Desa Jatiurip dengan bekerja di Home Industry Batik Tulis Dewi Rengganis. Hal tersebut dikarenakan selama menjadi ibu rumah tangga secara penuh, kreativitas dan produktivitas yang dimiliki kaum perempuan di Desa Jatiurip tidak pernah diasah. Hal ini dikarenakan mereka tidak dapat menyalurkan kreativitas dan produktivitas mereka dengan benar sehingga kemampuan yang dimiliki tersebut berujung sia-sia.

\subsection{Manfaat yang Diperoleh dari Kegiatan Pemberdayaan Perempuan dalam Perspekif Gender melalui Home Industry Batik Tulis Dewi Rengganis}

Ada dua sisi manfaat yang muncul dari kegiatan pemberdayaan perempuan yang dilakukan oleh home industry batik rengganis, yaitu dari sisi pihak pemberdaya maupun sisi yang diberdayakan. Adapun manfaat yang dirasakan oleh pihak pemberdaya yaitu: Adanya rasa bangga karena bisa menciptakan lapangan pekerjaan serta dapat mengurangi jumlah 
pengangguran di Desa Jatiurip. Pengangguran dapat terjadi karena ketidakseimbangan pada pasar tenaga kerja (Dongoran, 2016). Maksudnya adalah jumlah tenaga kerja yang ditawarkan melebihi jumlah tenaga kerja yang diminta.

Manfaat lain yaitu adanya kepuasan akan hasil produk batik yang diproduksi. Di mana pihak pemberdaya di sini dapat menyalurkan jiwa seni melalui coretan-coretan indah yang ada pada motif setiap kain batik yang diproduksi serta terwujudnya keinginan pihak pemberdaya dalam mengenalkan sejarah yang ada di Kabupaten Probolinggo kepada masyarakat luas dapat tersampaikan. Hal ini dikarenakan setiap motif yang ada di kain batik yang di produksi memiliki suatu makna atau menggambarkan suatu cerita sejarah di Kabupaten Probolinggo.

Manfaat juga dirasakan oleh para perempuan yang terlibat dalam kegiatan pemberdayaan. Ada beberapa manfaat yang dirasakan yaitu: Pertama, kegiatan pemberdayaan perempuan di Home Industry Batik Tulis Dewi Rengganis merubah status sosial dan perekonomian para perempuan yang bekerja di home industry tersebut. Hal ini dikarenakan mereka mendapat pendapatan yang dapat mereka gunakan dalam memenuhi setiap kebutuhan rumah tangga. Secara tidak langsung hal tersebut juga dapat mempengaruhi status sosial para pekerja perempuan yang semula hanya menjadi ibu rumah tangga secara penuh kini menjadi seorang perempuan pekerja. Kedua, terciptanya interaksi sosial dalam kegiatan pemberdayaan perempuan di Home Industry Batik Tulis Dewi Rengganis. Dengan adanya interaksi sosial yang tercipta antar pekerja, membuat para pekerja dapat menikmati setiap peran dalam pekerjaannya. Hal ini yang menyebabkan para pekerja perempuan di home industry Batik tulis Dewi Rengganis tidak merasakan suatu kejenuhan di saat jam bekerja. Selain itu, ketiga bertambahnya pengalaman dan pengetahuan setiap pekerja di Home Industry Batik Tulis Dewi Rengganis. Bagi mereka hal ini dimanfaatkan untuk menggali pengetahuan seputar proses membatik di Home Industry Batik Tulis Dewi Rengganis. Beberapa orang dari mereka berharap suatu saat bisa menciptakan lapangan pekerjaan sendiri yaitu dengan membangun suatu industry rumahan atau home industry, walaupun bukan dibidang produksi batik sama seperti yang saat ini dilakoni.

Manfaat yang terakhir yaitu kegiatan pemberdayaan ini secara tersirat dapat menekan jumlah pernikahan dini di Indonesia yang setiap tahunnya semakin meningkat. Dengan bergabung dan memiliki kesibukan sebagai pekerja di Home Industry Batik Tulis Dewi Rengganis dapat membuka pikiran pekerja perempuan yang belum menikah (usia belia) untuk tidak terburu-buru menikah dan mencari pengalaman sebanyak-banyaknya dengan ikut serta dalam kegiatan pemberdayaan khususnya di home industri batik tulis dewi rengganis.

\subsection{Faktor Pendorong dan Penghambat Kegiatan Pemberdayaan}

Dalam pelaksanaan kegiatan pemberdayaan perempuan yang dilakukan oleh batik tulis dewi rengganis, dalam perjalanannya terdapat beberapa faktor pendorong dan penghambat . Adapun faktor pendorong utama mereka bekerja keinginan untuk memenuhi kebutuhan keluarga. Hal ini dikarenakan seiring dengan perkembangan jaman, tuntutan hidup yang semakin tinggi, termasuk yang dibebankan kepada perempuan (Yusrini, 2017). Perempuan harus mampu ikut serta dalam menanggung beban ekonomi keluarga. Kebutuhan yang mendesak mampu mendobrak tradisi dan pandangan gender. Selain itu banyak dari mereka yang mayoritas adalah ibu rumah tangga pada akhirnya 
memutuskan bekerja pada industri rumahan sekedar untuk mengisi waktu kosong dan rasa jenuh selama mengurus rumah tangga.

Jika di atas membahas mengenai faktor pendorong para pekerja perempuan di Desa Jatiurip dan sekitarnya bersedia terlibat dalam kegiatan pemberdayaan perempuan di Home Industry Batik Tulis Dewi Rengganis, ada pula faktor penghambat mereka dalam bekerja. Menurut hasil penelitian, adapun faktor penghambat antara satu pekerja dengan pekerja lainnya berbeda-beda.

Faktor penghambat yang pertama adalah dikarenakan tidak semua pekerja di Home Industry Batik Tulis Dewi Rengganis memiliki jiwa seni dan sikap telaten atau sabar dalam mengikuti setiap rangkaian kegiatan pemberdayaan perempuan. Hal ini dikarenakan adanya rasa ingin segera memperoleh pendapatan. sehingga menyebabkan mereka tidak maksimal dalam mengikuti kegiatan pemberdayaan di Home Industry Batik Tulis Dewi Rengganis.

Faktor penghambat yang kedua yaitu jarak dari rumah ke Home Industry Batik Tulis Dewi Rengganis yang lumayan jauh. Hal ini dikarenakan tidak semua pekerja perempuan di Home Industry Batik Tulis Dewi Rengganis berasal dari Desa Jatirup. Ada beberapa dari mereka yang bahkan datang dari Desa tetangga yang setiap hari PP (Pulang Pergi) ketika hendak bekerja di Home Industry Batik Tulis Dewi Rengganis.

Hal lain juga di temukan di lapangan, di mana tidak semua pekerja perempuan di home industry Batik tulis Dewi Rengganis menganggap kesulitan-kesulitan yang ada sebagai penghambat mereka dalam bekerja. Justru sebaliknya, mereka merasa tidak ada hambatan yang berarti yang dapat mengganggu pekerjaan mereka di Home Industry Batik Tulis Dewi Rengganis. Mereka sangat menikmati peran mereka sebagai pekerja seni membatik di Home Industry Batik Tulis Dewi Rengganis.

\section{Simpulan}

Para perempuan yang bekerja di Home Industry Batik Tulis Dewi Rengganis sangat menikmati setiap detail pekerjaannya. Hal ini dikarenakan tidak adanya aturan yang ketat dan formal seperti ditempat kerja lainnya. Pemilik home industry lebih menekankan pada sistem bekerja yang santai tapi menghasilkan produk yang berkualitas. Hal tersebut didukung dengan adanya interaksi sosial yang terjalin antar pekerja yang semakin menambah kedekatan para pekerja di Home Industry Batik Tulis Dewi Rengganis. Dengan bekerja di Home Industry Batik Tulis Dewi Rengganis, para pekerja perempuan merasakan berbagai perubahan antara sebelum bekerja dan sesudah bekerja. Adapun perubahannya meliputi: Pertama yaitu meningkatnya kreativitas dan produktivitas para pekerja. Di mana sebelumnya mereka hanya sibuk mengurus rumah tangga secara penuh dan membuang waktu kosong mereka hanya untuk berdiam diri di rumah sehingga produktifitas dan kreatifitas mereka menurun. Yang kedua adanya sumber penghasilan tambahan untuk memenuhi kebutuhan hidup sehari-hari. Dan yang ketiga adanya persamaan nasib di mana mayoritas pekerja perempuan disini merupakan ibu rumah tangga. Hal tersebut yang menjadi faktor yang mendukung adanya interaksi antar pekerja perempuan. 
Jurnal Integrasi dan Harmoni Inovatif Ilmu-Ilmu Sosial (JIHI3S), Vol. 1 No. 1 (2021), 1-7

\section{Daftar Rujukan}

Dongoran, F. (2016). Analisis jumlah pengangguran dan ketenagakerjaan terhadap keberadaan usaha mikro kecil dan menengah di Kota Medan. EduTech: Jurnal Ilmu Pendidikan Dan Ilmu Sosial, 2(2), 59-72. https://doi.org/10.30596/edutech.v2i2.599

Miles, M., \& Huberman. (2002). Analisis Data Kualitatif. UI Press.

Nesneri, Y., \& Museliza, V. (2014). Motivasi wanita bekerja dan pengaruhnya terhadap kontribusi pendapatan wanita dalam membantu pendapatan keluarga di Kecamatan Marpoyan Damai Kota Pekanbaru. Marwah: Jurnal Perempuan, Agama Dan Jender, 13(1), 74. https://doi.org/10.24014/marwah.v13i1.883

Rahaju, M. E., Mulyawati, T., \& Sumarlan. (2012). Motivasi wanita bekerja dan pengaruhnya terhadap kontribusi pendapatan keluarga (studi kasus di Kecamatan Taman Kota Madya Madiun). Ekomaks, 1(2), 80-94. http://www.unmermadiun.ac.id/repository_jurnal_penelitian/Jurnal Ekomaks/Jurnal Ekomaks 2012/September/07 ML Endang hal 80-94.pdf

Sunartono. (2008). Analisis peningkatan kesempatan kerja di Indonesia. Jurnal Sains Dan Teknologi Indonesia, 10(1), 48-53. http://ejurnal.bppt.go.id/index.php/JSTI/article/download/791/624

Yusrini, A. (2017). Tenaga kerja wanita dalam perspektif gender di Nusa Tenggara Barat. JAL-MAIYYAH: Media Transformasi Gender Dalam Paradigma Sosial Keagamaan, 10(1), 115-131. https://doi.org/10.35905/almaiyyah.v10i1.452 